\title{
Corporate Criminal Liability or Other Criminal Law Measures in Respect of Legal Entities?
}

\author{
Nikolay V. Schedrin* and Alexey A. Vostokov \\ Siberian Federal University \\ 79 Svobodny, Krasnoyarsk, 660041, Russia
}

Received 09.04.2015, received in revised form 19.06.2015, accepted 13.08.2015

\begin{abstract}
Accepting the necessity of criminal law influence on criminal entities, authors of this article suggest the arguments against implementation of legal entities' criminal responsibility institution into the Russian system of criminal law. Instead of implementation of this institution the authors propose and support adoption of original model - "the other criminal law measures in respect of legal entities", which should include the following measures: safety measures, restoration measures and encouragement measures.
\end{abstract}

Keywords: measure, criminal, criminal law, responsibility, legal, entity, nature, code, safety, compensation, indemnity, restoration, encouragement.

DOI: 10.17516/1997-1370-2015-8-10-2100-2106.

Research area: law.

The problem of utilizing the criminal law potential against criminal organizations has been the focus of attention of the world legal community for a long time. A significant number of countries have come to the conclusion that corporate criminal liability (punishment) model should be applied and have reformed their criminal laws correspondingly. However, the conceptual approaches and models of domestic criminal law affect on legal entities vary significantly ${ }^{1}$.

Meanwhile Russian law-maker holds traditionally conservative position that only sane individuals of a certain age are subject to criminal liability. Nevertheless, the number of supporters for enlarging the range of subjects of criminal liability (crime) by means of legal entities is steadily growing. Supporters of corporate criminal liability, including such respected researches as E.Y. Antonova, B.V. Volzhenkin, E.N. Zhevlakov, L.V. Inogamova-Khegai, P.I. Karibov, S.G. Kelina, A.P. Kozlov, U.P. Kravetz, R.I. Minin, A.V. Naumov, A.S. Nikiforov, I.V. Sitkovsky, V.S. Ustinov, substantiate the need for such a step by the following arguments:

- Legal entities' immunity existed under conditions of Soviet monopoly to economic activity clearly does not correspond to the current state of economic life, where the legal entities are the main subjects of business activities and the activity of which relates to the most significant

(C) Siberian Federal University. All rights reserved

* Corresponding author E-mail address: sveroboy@mail.ru 
infringements on protected objects in terms of their devastating impact. It is clear that damage caused by organizations greatly exceeds the damage that may be caused by individual. At the same time the penalties applied to legal entities under civil and administrative law are not adequate to the extent of caused harm.

- The recognition of legal entities by civil and administrative branches of law as subjects to liability supports the introduction of such institution into criminal law as well. Moreover, in some cases, the boundaries between criminal offenses and corresponding administrative delicts are moving, and under certain circumstances and conditions, certain administrative offenses can transform into criminal offences and vice versa.

- Administrative and civil law sanctions do not result in proper preventive effect, particularly with regards to acts of legal entities posing an increased public danger. Such sanction as the "liquidation of the legal entity" is not provided by administrative law and is defined in civil law in its most general form.

- Bringing to responsibility the management or other representatives of a legal entity in its essence relates to the objective imputation, as even if such person was aware of illegal activities of the company producing, for instance, emissions of polluted water, but could not change anything by his own efforts. In some cases, it is difficult to determine who was really responsible for air or water pollution. Such criminal practice might last for years and decades, but only the person who was running the company at the moment when injurious to the public consequences occurred will be held liable.

- As usually happens with implementation of any new statute, the establishment of the institution of corporate criminal liability might face significant difficulties in the field of legislation and the law enforcement. However, careful scientific study may overpass such difficulties. Theuseofforeigncountriesexperience where the corporate criminal liability has been implemented for years might facilitates the implementation process. Moreover, international acts also contain sustainable recommendations regarding implementation of corporate criminal liability institution.

The reputable opponents of corporate criminal liability (namely M.I. Bazhanov, G. Bogush, G.N. Borzenkov, L.D. Ermakov, P. Ivantsov, T. Kondrashov, N.F. Kuznetsova, S.F. Miliukov, L.K. Savyuk etc.) suggest their following arguments against corporate criminal liability:

- according to the Russian tradition, only those individuals who intentionally or negligently committed criminal acts may be subject to criminal liability. The existing criminal law connects liability to the ability of individual committing a crime to act consciously which is attributable to human only. Since an organization has no will and consciousness, it cannot be responsible for any act committed;

- the introduction of corporate criminal liability would result in review of the basic principles of criminal law and in significant changes to the criminal law. That would require the Criminal Code to provide two systems of principles and grounds of criminal liability and punishment. The said novelties will lead to fundamental changes not only in material but also in procedural and correctional laws;

- the corporate civil and administrative liability has been implemented in Russian law already. The potential of these branches of law may be enforced and developed by introducing the missing sanctions and strengthening existing ones;

- specific research support the idea that introduction of corporate criminal liability 
is premature. Firstly, the institute hardly "fits" into the system of administrative law, in this connection it brings a lot of enforcement problems. Secondly, in case the said institution "malfunctions" in administrative law then the effectiveness of criminal liability in this respect is doubtful.

It is obvious that both sides have substantial arguments. "Reformers" are right that dangerous activities of some organizations might be of a highest threat to society, thereby it is worth using "heavy artillery" - criminal law - to fight against it. But "conservatives" objections are also convincing: the proposed scenario of "adjusting" the criminal law to legal entities is connected with a mass of obvious andhidden difficulties, thusnegative consequences of the reform might outweigh positive.

To overcome the lasting dispute over the corporate criminal liability a compromise has been suggested. For instance, E. Kuritsina, suggests defining legal entities as instruments of crime, which are being employed by individuals to accomplish their criminal intentions. Thus, according to Art. 81 of the Criminal Code, a legal entity (or incorporation documents) can be regarded as material evidence, with all the ensuing consequences ${ }^{2}$.

In 2006 we have suggested and substantiated an alternative approach ${ }^{3}$ that, on the one hand, allows abandoning the "criminal responsibility (the punishment) of legal entities" model, which implementation entails the obligatory presence of the subjective elements of the crime - the presence of legal capacity of organization and guilt, and on the other hand to recognize criminal organizations as a separate criminal law subject.

Our approach is based on "multi-track" nature of the current Russian criminal law. In accordance with this approach Russian criminal law includes four types of legal consequences: punishment sanctions, recovery (compensation) sanctions, security sanctions and stimulation sanctions ${ }^{4}$. The said approach is not fundamentally new. The idea itself has been borrowed from the formal criminal law doctrines of the Germanspeaking countries.

Austria, Germany and Switzerland define their penal systems as "twin-track" (das zweispurige System), i.e. having two types of legal consequences of criminal offense: punishments (die Strafe) and security sanctions (die Massregeln der Siecherung). As some German researchers admit, in recent times the German criminal law has obtained the third "track" - the recovery measure (die Wiedergutmachung) .

Modern Russian criminal law system is at least "two-track". Division of legal consequences of a crime into "punishment" and "other criminal law measures" is now universally accepted. Two kinds of legal consequences have been stipulated by Art. 2 of the Russian Criminal Code (1996), supported by introduction of Chapter 15.1 "Confiscation of property" alongside with changing the title of Part VI of the Criminal Code into "Other criminal law measures" (2006).

Taking into consideration a "twin-track" principle the majority of ideas of criminal law effect on criminal organizations seem quite strange: one "track" - liability (punishment) is massively promoted, and the other - other criminal law measures - totally ignored. Why not doing vice versa?

The category of "criminal liability" forces its supporters to use two related categories: "guilt" and "punishment". But the ascertainment of "guilt" implies a certain level of intellect and will, both appropriate when dealing with individuals only, not all though. Attempts to adapt the same category to legal entities result in complicated and hardly efficient irrational constructions. 
Criminal punishment has a personal nature, therefore it can be applied to individuals only. To be more exact, to those socially and mentally mature individuals, able to act rationally weighting the advantages and disadvantages of crime and punishment. "Punishment" of a legal entity being an obvious legal fiction seems as useless and absurd as punishment of stones, bells or animals.

Ourresearch revealed that majority of liability measures (penalties) proposed by supporters of corporate criminal liability may exist in the form of other criminal law measures, which are security, restoration and stimulation measures ${ }^{6}$. The said approach conforms to the classical theory of criminal law, logically fits into the modern system of the Russian criminal law, conciliates the "reformers" and "conservatives" and enables to qualify organizations as subjects to criminal law measures.

Security measures (sanctions) restrict the socially dangerous activity. They can be appliednotonly to individuals but to organizations as well. Unlike punishment security measures may be applied right upon the fact of commitment of socially dangerous act specified in Articles of Special Part of the Criminal Code and do not require subjective elements of the offense - all features of proper subject (legal capacity and ability to act) and subjective aspect (goal object, motive and guilt). Consequently, security measures can be applied to any entity including criminal organizations and shadow economy participants who are rarely duly incorporated. A sufficient ground to impose security sanctions to an entity comprises three proven facts: a) an act performed by legal entity is prohibited by criminal law, and b) the consequences of crime have occurred, and c) a presence of causal connection between the act and criminal consequences. In this case, there is no need to prove a legal capacity of legal entity.
In our opinion, a substantial part of criminal law measures being employed in other countries and offered de lege ferenda in Russia have much in common with security measures. The only exception is a fine, which might be equivalently replaced by two types of confiscation: special confiscation (security sanction) or recovery confiscation (compensation sanction). Having changed the status of the confiscation from punishment to the other measure of criminal law, Russian law-maker has made it applicable to criminal organizations.

Moreover, in our view, the current edition of Chapter 15.1 of the Criminal Code entitled "Confiscation of property" contains rules supporting the idea of the confiscation application to legal entities. Under Art. 104.1 of the Russian Criminal Code a convicted person's property transferred to other person (organization) is subject to confiscation in case the transferee knew or should have known that the property was obtained illegally. Thus, Art. 104.1 of the Russian Criminal Code already permits implementation of confiscation of property to organization (legal entity), provided that the said entity was purposely used by criminals for money laundering.

We believe that provisions of the Russian Criminal Code should not be limited to confiscation of organizations' property obtained from individual criminals. The purpose of confiscation should not be narrowed to confiscation of: a) property obtained by illegal means to be returned to its legal possessor, the instruments and means of committing crimes, and b) money and other property used or intended to finance terrorists and criminal associations, and c) tools, equipment and other instruments of crime. Confiscation should be used as a measure of rehabilitation and compensation.

Considering the said above we suggest the following: 
1. Do not be limited to the "legal entity" for the purposes of implementation of criminal law measures in respect of collective subjects of law. At the present time many collective subjects that have all characteristics of legal entities, except for the governmental registration as legal entity, commit the most dangerous crimes. In order to put the said collective subjects in the sphere of criminal law the general notion "organization" (one of the types of which shall be legal entity) should be introduced to the criminal law.

2. "Act prohibited by criminal law" must become a legal fact for application of criminal law measures rather than a "crime" or "act containing all characteristics of crime elements". For the purposes of criminal law repression economy, a possibility to apply security measures in respect of organizations should be provided only for the acts objective aspect of which is explicitly provided by the Criminal Code. Such acts should comprise extremist and terroristic activities, money laundering, drug and human trafficking, arms trafficking, as well as other the most socially dangerous acts against ecology, peace and security.

3. To introduce a new chapter to the Criminal Code - "Criminal law measures in respect of organizations", providing a list of security measures, recovery (compensation) measures and stimulation measures applicable to organizations committing acts prohibited by criminal law.

The said chapter should define, formulate goals, objectives and general provisions of implementation of the said measures. At the same time it should be explicitly specified that the said measures can be applied both to organizations (collective subjects of law) having legal status of legal entities and to organizations not registered as legal entity under applicable procedure.
4. To introduce a list of following measures applicable to collective subjects (organizations) being legal entities: disfranchisement, license revocation, freedom to operate restriction (organization is subject to administrative supervision, seizure of property, restriction or prohibition for certain activities, placing of other special duties), liquidation, publication ofjudgementon security measures application, special confiscation of property.

The following security sanctions should be applied to collective subjects (organizations) which are not legal entities: prohibition for activity, introducing of organization to the list of criminal organizations (which will be officially published), the special confiscation of organizations' property.

Criminal fine may be replaced with recovery measures (compensation) for the damage caused by socially dangerous and criminal activity of organizations. Such measures include recovery confiscation.

The proposed chapter should also contain criminal law stimulation measures, i.e. measures that remedy criminal law burden for organizations collaborating with authorities and willing to recover damages.

5. Introducing to the list of criminal organizations creates predjudgement for subsequent application of constitutional, administrative, and civil sanctions. Participation of individuals in such organizations should be criminalized and prosecuted.

6. With the possibility of application of other criminal law measures in respect of legal entities corresponding provisions of criminal procedural law and correctional law should also be appropriately amended. The strict regulations of the criminal law procedure would minimize the political abuse of discretion in this area. 
In our opinion the proposed scenario is realistic based on the experience of Spain and Latvia, where the use of corporate criminal liability and criminal punishment was renounced in favor of other criminal law measures.

A.V. Maleshina, V.A. Nomokonov, V.A. Pimonov, A.G. Korchagin, N.F. Kuznetsova and other scientists share the idea of application of other criminal law measures in respect of criminal organizations. E.Y. Antonova, one of the consistent supporters of the corporate (collective) liability, has recently changed her position and offered the introduction of "twin-track" system: 1) criminal liability (punishment) with the establishment of guilt - in respect of legal entities and 2) other criminal law measures ${ }^{7}$ - in respect of organizations not registered as legal entities.

«Criminal law measures in respect of organizations» model was taken as a basis of a draft law, which has been recently submitted to the Russian parliament by the Russian Investigative Committee ${ }^{8}$.

1 For more detailed information see: Antonova E.Y. Conceptual framework of corporate (collective) criminal liablity. SPb.: "Legal centre-Press", 2011. P. 29-112.

2 Kuritsina E. Legal entity as a tool of a crime // Russian justice. 2001. № 2. P. 25.

3 See: Schedrin N.V. Corporate criminal liability or criminal security sanctions in respect of collective bodies? // Actual issues of crime prevention in Siberian territory: International conference source book. (16-17 February 2006). In 2 parts. / Siberian Law Institute of Ministry of internal affairs of Russia. - Krasnoyarsk. 2006. Part.1. P. 25; Schedrin N.V., Vostokov A.A. Corporate criminal liability or other criminal measures in respect of organizations // Criminal law. 2009. № 1. P. $58-61$.

4 Schedrin N.V. Four “tracks” of Russian criminal law (article) // Criminal law. 2008. № 4. P. 59 - 62.

5 Roxin, Claus. Strafrecht. Allgemeiner Teil. Band 1. Verlag Beck. 3 Aufl. Muenchen. - 1997. - P. 3.

6 Conceptually-theoretical basis of legal regulation and implementation of security measures: monograph / under the editorship of N.V. Schedrin; Siberian Federal University. Krasnoyarsk: SFU, 2010. 324 p.

7 See.: Antonova E.Y. The said publications. P. 295-327.

8 Federal law project "On introduction of amendments to certain legal acts of the Russian Federation in connection with introduction of criminal law influence to legal entities institution". Published at the web-site of "Rossiiyskaya Gazeta" on 12 October $2011 / /$ http://www.rg.ru/2011/10/12/proekt-site-dok.html

\section{References}

Antonova E.Y. Conceptual framework of corporate (collective) criminal liablity. SPb.: "Legal centre-Press", 2011.

Conceptually-theoretical basis of legal regulation and implementation of security measures: monograph / under the editorship of N.V. Schedrin; Siberian Federal University. Krasnoyarsk: SFU, 2010.

Kuritsina E. Legal entity as a tool of a crime // Russian justice. 2001. № 2.

Roxin, Claus. Strafrecht. Allgemeiner Teil. Band 1. Verlag Beck. 3 Aufl. Muenchen. 1997.

Schedrin N.V. Corporate criminal liability or criminal security sanctions in respect of collective bodies? // Actual issues of crime prevention in Siberian territory: International conference source book. (16-17 February 2006). In 2 parts. / Siberian Law Institute of Ministry of internal affairs of Russia. Krasnoyarsk. 2006. Part.1.

Schedrin N.V. Four "tracks” of Russian criminal law (article) // Criminal law. 2008. № 4.

Schedrin N.V., Vostokov A.A. Corporate criminal liability or other criminal measures in respect of organizations // Criminal law. 2009. № 1.

Federal law project "On introduction of amendments to certain legal acts of the Russian Federation in connection with introduction of criminal law influence to legal entities institution”. Published at the 
web-site of "Rossiiyskaya Gazeta" on 12 October 2011 // http://www.rg.ru/2011/10/12/proekt-site-dok. html.

\title{
Корпоративная уголовная ответственность \\ или иные меры уголовно-правового характера?
}

\author{
Н.В. Щедрин, А.А. Востоков \\ Сибирский федеральный университет \\ Россия, 660041, Красноярск, пр. Свободный, 79
}

\begin{abstract}
Принимая во внимание неизбежность воздействия уголовного права на юридические лица, авторы данной статьи предлагают аргументацию против введения уголовной ответственности для юридических лиц в российскую систему уголовного права. Вместо этого авторы предлагают и выступают в поддержку принятия оригинальной модели «иных мер уголовно-правового характера в отночении юридических лиц», которая будет включать в себя следующее: меры безопасности, меры восстановления и меры поощрения.
\end{abstract}

Ключевые слова: мера, уголовный, уголовное право, ответственность, юридическое лицо, природа, кодекс, безопасность, компенсация, защчита от ответственности, восстановление, поомрение.

Научная специальность: 12.00.00 - юридические науки. 